\title{
Effect of Silver Nanoparticles Treatments on Some Characteristics of "Santander" Lily Cultivar
}

\author{
Onur Sefa Alkaç,a,", Osman Nuri Öcalan ${ }^{1, b}$, Mehmet Güneș ${ }^{1, c}$ \\ ${ }^{I}$ Department of Horticulture, Faculty of Agriculture, Tokat Gaziosmanpasa University, 60010 Tokat, Turkey \\ *Corresponding author

A R T I C L E I N F O A B S T R A C T \\ Research Article \\ The use of silver nanoparticles (AgNPs) in the fields of agriculture and horticulture has been \\ increasing recently due to contribution to seed germination, plant growth and development, \\ flowering, yield, and physiological improvements. This research aimed to investigate the effects of \\ silver nanoparticles on the growth and flowering characteristics of the 'Santander' lily (Lilium L.) \\ Received : 19/04/2021 \\ Accepted : 12/01/2022 \\ variety and to determine its potential for use in cultivation. Before planting the plant bulbs immersed \\ in AgNPs solutions of 0 (control), 50, 75, 100, 125 and $150 \mathrm{ppm}$. After harvest; weight, \\ circumference, height, root length, fresh and dry weight, stem root length, fresh and dry weight of \\ stem, plant height, plant stem diameter, fresh plant weight, bud number and vase life were \\ determined. As a result; it has been indicated that AgNPs solutions in different concentrations \\ increased the quality and quantity of cut flowers and bulbs in lily plants. AgNPs increased an \\ Keywords: \\ Lilium sp. \\ Nanomaterial \\ Silver nanoparticle \\ Cut flower \\ Plant growth promoter \\ average of $26.29 \%$ when compared with control in all morphological characteristics except for the \\ vase life. In the light of these findings, AgNPs applications can be preferred as a method that can \\ be used on lily cultivation and reproduction. Nevertheless, considering the deficiency of treatments \\ of AgNPs in lily plants and their poorly known effect on plants, further detailed studies are \\ necessary.
}

\section{Introduction}

Lilies (Lilium sp. and hybrids) are the second-major flower bulb product in the Netherlands and the greatest importance bulb product in the world. Lilies are culivated for bulbs, cut flowers, potted or garden flowers. The majority of bulbs cultivated for worldwide distribution are grown mainly in the Netherlands and lilies the fifth most desirable cut flower after roses, chrysanthemums, tulips, and gerberas, respectively. In 2019, cut lily flowers were 144 million and bulb production were 282 million pieces for Europe (Royal Flora Holland, 2019). Lily bulbs are also grown in USA, Israel, Brazil, Australia, New Zealand, Tasmania and Chile. (Chastagner et al., 2017).

Recently, metallic nanoparticles which have an important place in nanotechnology, find application opportunities in many fields such as physics, chemistry, electronics, food, health and biomedical and are the subject of intensive studies in this field. Looking at ancient times, it is seen that the shelf life extended at room temperature by throwing silver coins into water and milk, and success achieved in food preservation by using silver containers and tools. It is reported that silver is used as an antimicrobial agent in waters used in the Russian MIR space station and NASA space shuttle (Beykaya and Çağlar, 2016).

The use of AgNPs in agricultural and horticultural fields has recently increased due to their contribution to plants physiological improvements (Byczyńska, 2017a). The positive effects of AgNPs increased vase life in cut alstroemeria (Alstroemeria 'Summer Sky') (Langroudi et al., 2020), extended post-harvest life of cut 'White Parrot' Tulipa flowers (Byczyńska, 2017b), supported growth and enhancement of inflorescences in Carthamus tinctorius (Zari et al., 2015). AgNPs treatment by decreasing stem blockages delays the senescence of cut Antirrhinum flowers (Rabiza-Świder, 2020). In Trigonella foenumgraecum, the treatment of AgNPs stimulated the development of seedlings by increasing root length, shoot length, leaf number, and fresh weight of plants (Jasim, 2017). Soaking the bulbs in the AgNPs solution enhances the quality of cut flowers, increases bulb yield, promotes 
the development of the root system and shortens the production cycle (Byczyńska, 2019). It has been determined that AgNPs applications show different effects of nematicidal activity (Dura et al., 2019). Silver nanoparticles may also have inhibitor effects, manifested by limited germination in Brassica nigra (Amooaghaie, 2015). AgNPs stimulated plant growth, as manifested by the enhanced accumulation of leaf and bulb biomass and accelerated flowering (Salachna, 2019).

Due to the limited number of studies on the effects of AgNPs on lily plants, this study was conducted to determine what kind of effect they have by choosing different concentrations than the concentrations preferred in previous studies. In this study, we examined the impacts of bulb immersing in nano-silver solutions of varied concentrations on the quality parameters of plant growth of 'Santander' lilies. It is known that especially plant height, number of buds and vase life parameters are more important than other parameters in these quality parameters.

\section{Material and Method}

This study carried out in the greenhouse $\left(40^{\circ} 19^{\prime} 55^{\prime \prime} \mathrm{N}\right.$ $36^{\circ} 28^{\prime} 33^{\prime \prime E}$ ) in 2020 using bulbs of Lilium spp cv. Santander. The bulbs were obtained from 'Asya Lale' company. The average circumference and weight of bulbs were $13.35 \mathrm{~cm}$ and $31.80 \mathrm{~g}$, respectively (Figure 1). Before planting, the bulbs immersed for $60 \mathrm{~min}$ in AgNPs (Nanography, Turkey) solutions $(0,50,75,100,125$, and $150 \mathrm{ppm}$ ) prepared by dissolving AgNPs in pure water.

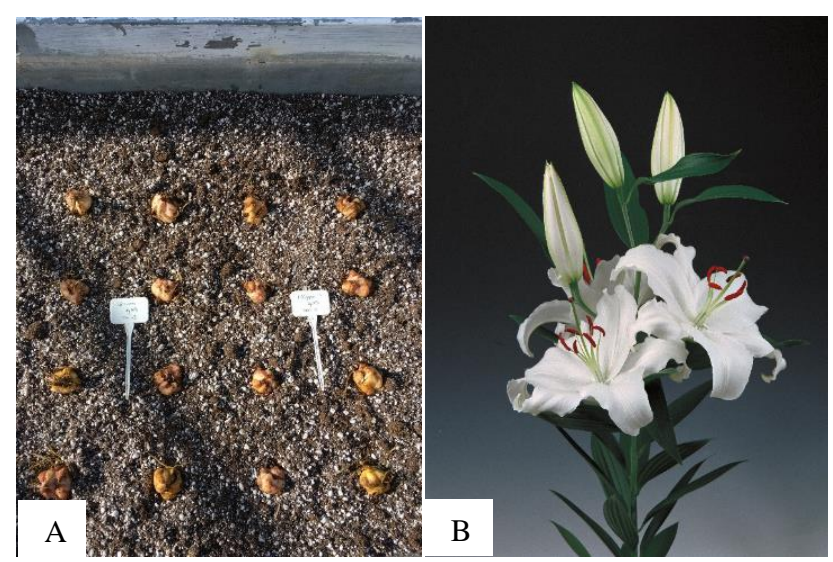

Figure 1. Lily 'Santander' bulbs (A) and flowering (B, Anonymous, 2022).

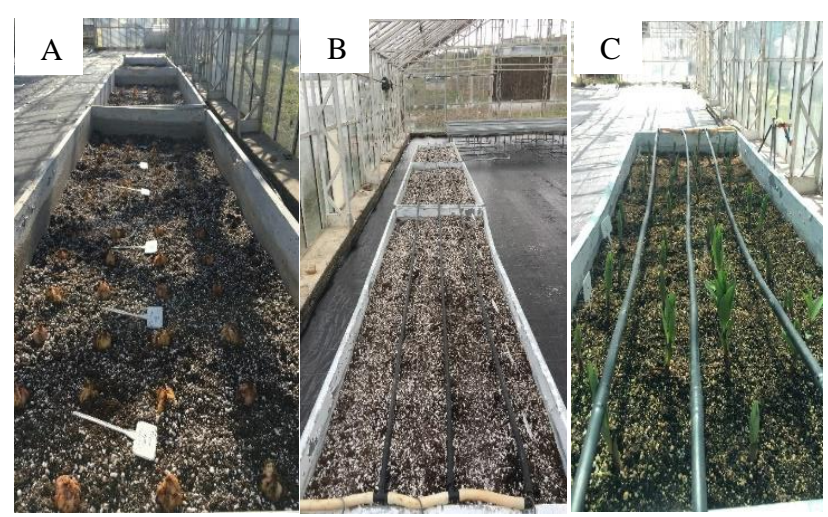

Figure 2. Lily 'Santander' planting (A), covering the bulbs (B), one month after planting (C)
Each treatment involved three independent repetitions with eight bulbs (Total bulbs 144 pieces). On 13 April 2020 , each bulb planted with a distance of $15 \mathrm{~cm}$ into the growing tables. Growing tables have $80 \mathrm{~cm}$ diameter, 240 cm length, and $384 \mathrm{~L}$ capacity filled equally (1:2) with perlite and peat material TS1 (Kronen, Cerkwica, Poland) (100-200 mg/l N, 70-130 mg/l $\mathrm{P}_{2} \mathrm{O}_{5}, 140-240 \mathrm{mg} / \mathrm{l} \mathrm{K} \mathrm{O}_{2} \mathrm{O}$ ve $60-100 \mathrm{mg} / \mathrm{l} \mathrm{Mg}$ ). The peat material has an initial $\mathrm{pH}$ of 5.5 -6.5 and an electrical conductivity of $35 \mathrm{mS} / \mathrm{m}^{-1}$. (Figure 2). The average temperature and humidity were $25.8^{\circ} \mathrm{C}$ and $\% 74.7$ in the greenhouse during the study.

Plants were harvested (14 weeks after planting) when the fully colored flower bud appeared. Then six plants from each replicate were randomly picked up for the following measurements; bulb weight $(\mathrm{g})$, bulb circumference $(\mathrm{cm})$, bulb size $(\mathrm{mm})$, stem root length $(\mathrm{cm})$, bulb root length (cm) measured from the basal plate to the end of the longest root, fresh weight of stem root (g), fresh weight of bulb root $(\mathrm{g})$, dry weight of stem root $(\mathrm{g})$, dry weight of bulb root $(\mathrm{g})$, plant height $(\mathrm{cm})$, stem diameter $(\mathrm{mm})$, bud number (pieces per plant), the weight of fresh cut-flower (g) and vase life (day). The harvested flowers were first hydrated. The dewatered plants were transferred to vases. They have two buds in all the flowers in the vase. Post-harvest vase life was measured daily, cut flowers placed in individual glass bottles with a capacity of $250 \mathrm{~mL}$ filled with pure water. Thereafter cut flowers were placed in a controlled environment at $21 \pm 2{ }^{\circ} \mathrm{C}, 60 \pm 5 \%$ relative humidity with a cycle of $13 \mathrm{~h}$ of light and $11 \mathrm{~h}$ of darkness. Loss of the ornamental (aesthetic) values was evaluated as wilting and drying of petals (Byczyńska, 2019).

Data analyzed with One-Way ANOVA for univariate experiments and set up according to the randomized plot trial design with three replications. Calculations were implemented using SPSS Statistics 17.0. A comparison of means and specification of homogeneous groups dependent on the Duncan test for $\alpha=0.05$.

\section{Results and Discussion}

Using 14 different bulb and flower parameters, this study examined the effect of AgNPs application on 'Santander' Lilium bulbs. Results showed that except for the bulb root length, there were no significant differences $(\mathrm{P}<0.05)$ among treatments. The $125 \mathrm{ppm}$ AgNPs increased bulb root length by $26.54 \%$ compared to control (Table 1 ).

The bulb weight varied from 16.1 to $17.68 \mathrm{~g}$, the bulb circumference varied from 11.43 to $12.12 \mathrm{~cm}$, the bulb size varied from 37.03 to $39.73 \mathrm{~mm}$, the stem root length of the bulb varied from 15.79 to $17.83 \mathrm{~cm}$, the bulb root length varied from 11.65 to $15.21 \mathrm{~cm}$, the wet weight of stem root varied from 13.15 to $15.83 \mathrm{~g}$, the wet weight of bulb root varied from 0.92 to $1.73 \mathrm{~g}$, the dry weight of stem root varied from 2.17 to $2.52 \mathrm{~g}$, the dry weight of bulb root from 0.13 to $0.29 \mathrm{~g}$, the plant height varied from 75.83 to 79.57 $\mathrm{cm}$, the plant stem diameter varied from 5.47 to $5.74 \mathrm{~mm}$, the fresh cut-flower weight varied from 63.13 to $75.34 \mathrm{~g}$, the number of flower bud varied from 2.19 to 2.44 , the vase life varied from 10.33 to 12.33 days (Table 1 ).

The obtained results in our study were similar with other researchers working on these issues. Pallavi et al. (2016) revealed that Vigna sinensis plants sprayed with 50 ppm AgNPs encouraged longer and heavier shots. 
Table 1. Effects of AgNPs concentrations on morphological characteristics of lily

\begin{tabular}{|c|c|c|c|c|c|c|c|}
\hline AgNPs (ppm) & $\begin{array}{l}\text { Bulb weight } \\
\text { (g) }\end{array}$ & $\begin{array}{c}\text { Bulb } \\
\text { circumference } \\
(\mathrm{cm})\end{array}$ & $\begin{array}{l}\text { Bulb size } \\
\quad(\mathrm{mm})\end{array}$ & $\begin{array}{l}\text { Stem root length } \\
(\mathrm{cm})\end{array}$ & $\begin{array}{l}\text { Bulb root length } \\
\qquad(\mathrm{cm})\end{array}$ & $\begin{array}{l}\text { Fresh weight } \\
\text { of stem root } \\
(\mathrm{g})\end{array}$ & $\begin{array}{l}\text { Fresh weight } \\
\text { of bulb root } \\
(\mathrm{g})\end{array}$ \\
\hline 0 & $16.10 \pm 3.63$ & $11.43 \pm 1.32$ & $38.69 \pm 0.41$ & $16.64 \pm 1.69$ & $12.02 \pm 0.97^{\mathrm{b}}$ & $14.58 \pm 2.47$ & $0.92 \pm 0.46$ \\
\hline 50 & $17.68 \pm 1.85$ & $12.12 \pm 0.59$ & $39.04 \pm 0.2$ & $15.79 \pm 1.15$ & $11.65 \pm 1.86^{\mathrm{b}}$ & $14.59 \pm 3.26$ & $1.03 \pm 0.72$ \\
\hline 75 & $17.00 \pm 1.34$ & $11.67 \pm 0.3$ & $39.06 \pm 1.35$ & $17.83 \pm 0.82$ & $14.75 \pm 0.9^{a}$ & $13.64 \pm 4.48$ & $1.65 \pm 0.11$ \\
\hline 100 & $16.37 \pm 0.79$ & $12.01 \pm 1.2$ & $38.68 \pm 0.5$ & $16.55 \pm 1.81$ & $11.88 \pm 1.62^{b}$ & $13.82 \pm 0.04$ & $1.23 \pm 0.34$ \\
\hline 125 & $16.35 \pm 2.35$ & $11.68 \pm 0.96$ & $37.03 \pm 0.97$ & $17.71 \pm 0.55$ & $15.21 \pm 0.75^{\mathrm{a}}$ & $13.15 \pm 0.64$ & $1.73 \pm 0.06$ \\
\hline 150 & $16.54 \pm 2.62$ & $11.69 \pm 0.86$ & $39.73 \pm 3.08$ & $17.77 \pm 1.26$ & $13.01 \pm 1.43^{\mathrm{ab}}$ & $15.83 \pm 1.11$ & $1.25 \pm 0.23$ \\
\hline $\begin{array}{l}\text { Significance } \\
\text { coefficient }\end{array}$ & 0,961 & 0,950 & 0,383 & 0,334 & $0,021 *$ & 0,827 & 0,137 \\
\hline AgNPs (ppm) & $\begin{array}{c}\text { A dry } \\
\text { weight of } \\
\text { stem root }(\mathrm{g})\end{array}$ & $\begin{array}{c}\text { A dry } \\
\text { weight of bulb } \\
\text { root }(\mathrm{g})\end{array}$ & $\begin{array}{l}\text { Plant height } \\
\text { (cm) }\end{array}$ & $\begin{array}{c}\text { Plant stem } \\
\text { diameter }(\mathrm{mm})\end{array}$ & $\begin{array}{l}\text { Fresh cut-flower } \\
\text { weight }(\mathrm{g})\end{array}$ & $\begin{array}{l}\text { Number of a } \\
\text { flower bud } \\
\text { (per plant) }\end{array}$ & $\begin{array}{l}\text { Vase life } \\
\text { (day) }\end{array}$ \\
\hline 0 & $2.35 \pm 0.57$ & $0.13 \pm 0.03$ & $76.69 \pm 1.98$ & $5.6 \pm 0.06$ & $70.77 \pm 5.58$ & $2.31 \pm 0.07$ & $12.33 \pm 2.52$ \\
\hline 50 & $2.34 \pm 0.89$ & $0.29 \pm 0.22$ & $77.86 \pm 2.46$ & $5.74 \pm 0.17$ & $75.34 \pm 5.49$ & $2.44 \pm 0.27$ & $10.67 \pm 2.89$ \\
\hline 75 & $2.17 \pm 0.52$ & $0.19 \pm 0.05$ & $79.44 \pm 4.7$ & $5.63 \pm 0.19$ & $72.15 \pm 8.84$ & $2.25 \pm 0.1$ & $10.67 \pm 1.15$ \\
\hline 100 & $2.36 \pm 0.22$ & $0.17 \pm 0.03$ & $79.57 \pm 1.9$ & $5.63 \pm 0.29$ & $72.76 \pm 4.28$ & $2.19 \pm 0.22$ & $12.33 \pm 3.21$ \\
\hline 125 & $2.30 \pm 0.41$ & $0.27 \pm 0.11$ & $75.85 \pm 1.15$ & $5.47 \pm 0.15$ & $63.13 \pm 2.28$ & $2.00 \pm 0$ & $10.33 \pm 0.58$ \\
\hline 150 & $2.52 \pm 0.28$ & $0.17 \pm 0.02$ & $75.83 \pm 2.19$ & $5.66 \pm 0.27$ & $70.24 \pm 5.25$ & $2.28 \pm 0.25$ & $11.33 \pm 1.15$ \\
\hline $\begin{array}{l}\text { Significance } \\
\text { coefficient }\end{array}$ & 0.981 & 0.317 & 0.351 & 0.723 & 0.230 & 0.161 & 0.772 \\
\hline
\end{tabular}

*: Statistically significant at $\mathrm{P}<0.05$ level. \pm : Standard deviation

It has revealed that $60 \mathrm{ppm}$ AgNPs application has a stimulating effect on the development and weight of Ocimum basilicum plant (Nematzadeh-Barondozi et al., 2014). The stimulating impact of AgNPs on plant development also appeared in Cucumis sativus (Shams et al., 2013), Chrysanthemum morifolium (Tung et al. 2018), and Phaseolus vulgaris (Das et al. 2018). Feregrino et al. (2018) found that the impact of AgNPs on the growth and development of plants may be connected to the fact that silver-nanoparticles may enhance metabolic processes that lead to plant growth encouraging or restriction in general. Das et al. (2018) reported that nano-silver particles strengthen plant growth by developing the improvement of necessary macronutrients uptake by roots. Syu et al. (2014) found that with AgNPs application, Arabidopsis gene expression connected to metabolism and hormone signaling pathways and cell division. Barabanov et al. (2018) has reported that immersed seeds in AgNPs positively impacted root length in Pisum sativum. Same way, our study has been observed a positive effect on stems and bulb roots in AgNPs applications.

AgNPs used in our study allowed us to achieve usually higher quality and quantity parameters than ones produced as the control. Higher quantity and quality parameters of lily yield may be thanks to improving effects of AgNPs on the growth of the plant. It needs to be better investigating the application of AgNPs and the mechanism of action in the diffusion of other ornamental bulbs.

\section{Conclusion}

As a result, it was concluded that soaking lily bulbs in AgNP increased the quality of growth, flowering, and bulb except for the vase life parameter compared to the control. In the light of these findings, AgNPs can be preferred as agents that can be used in growing ornamental bulb plants and may be very useful due to their unique properties. But in lily plants, considering the insufficiency, negative effect on vase life, and little-known effects on plants of AgNPs treatments, there are needed for more detailed studies with different treatment methods. Nevertheless, as their mechanisms of action are not fully understood, further detailed mycological, biochemical, and molecular studies in order to impact of nanosilver on plant health and stress are necessary.

\section{Statement of Conflict of Interest}

The authors declare that they are no conflict of interest.

\section{Authors' Contributions}

Onur Sefa Alkaç

Experiment idea, installation of the experiment, field analysis, data collection and analysis.

\section{Osman Nuri Öcalan}

Installation of the experiment, analysis, and interpretation of data, critical review of the article.

Mehmet Güneş

Advisor of work, preparation, and writing of the article, critical review, interpretation, translation, approval of the final version of the article.

\section{References}

Amooaghaie R, Tabatabaei F, Ahadi AM. 2015. Role of hematin and sodium nitroprusside in regulating Brassica nigra seed germination under nano-silver and silver nitrate stresses. Ecotoxicology and Environmental Safety, 113: 259-270.

Anonymous 2022. Lily 'Santander' Picture. https://www. vletterdenhaan.com/santander. [Accessed 20 January 2022].

Barabanov PV, Gerasimov AV, Blinov AV, Kravtsov AA, Kravtsov VA. 2018. Influence of nanosilver on the efficiency of Pisum sativum crops germination. Ecotoxicology and Environmental Safety, 147: 715-719. 
Beykaya M, Çağlar A. 2016. Bitkisel özütler kullanılarak gümüşnanopartikül (AgNP) sentezlenmesi ve antimikrobiyal etkinlikleri üzerine bir araştırma. Afyon Kocatepe Üniv. Fen ve Mühendislik Bilimleri Derg., 16(3): 631-641.

Byczyńska A. 2017a. Nano-silver as a potential biostimulant for plant-A review. World Sci. News, 86(3): 180-192.

Byczyńska A, 2017b. Improvement of post-harvest quality of cut tulip 'White Parrot 'by nano silver. World Sci. News, 83: 224228.

Byczyńska A, Zawadzińska A, Salachna P. 2019. Silver nanoparticles preplant bulb soaking affects tulip production. Acta Agric. Scandinavica, Section B-Soil Plant Sci, 69(3): 250-256.

Chastagner GA, Van Tuyl JM, Verbeek M, Miller W. Westerdahl, B. B. 2017. Diseases of lily. In handbook of florists' crops diseases, handbook of plant disease management, springer international publishing, pp. 12291288.

Das P, Barua S, Sarkar S, Karak N, Bhattacharyya P, Raza N, Kim KH, Bhattacharya SS. 2018. Plant extract-mediated green silver nanoparticles: efficacy as soil conditioner and plant growth promoter. J Hazard Mater., 346: 62-72.

Dura O, Tülek A, Sönmez İ, Erdoğuş FD, Yeşilayer A, Kepenekci İ. 2019. Effects of silver nanoparticle (AgNPs) applications prepared using Lantana camara L. (Lamiales: Verbenaceae)'s aqueous extract on wheat gal nematode [Anguina tritici Thorne, 1949 (Nematoda: Anguinidae)]. Bitki Koruma Bülteni, 59(2): 49-53.

Feregrino-Perez AA, Magaña-López E, Guzmán C, Esquivel K. 2018. A general overview of the benefits and possible negative effects of the nanotechnology in horticulture. Sci. Hortic., 238: 126-137.

Jasim B, Thomas R, Mathew J, Radhakrishnan EK. 2017. Plant growth and diosgenin enhancement effect of silver nanoparticles in Fenugreek (Trigonella foenum-graecum L.). Saudi Pharmaceutical J., 25(3): 443-447.
Langroudi ME, Hashemabadi D, KalateJari S, Asadpour L. 2020. Effects of silver nanoparticles, chemical treatments and herbal essential oils on the vase life of cut alstroemeria (Alstroemeria 'Summer Sky') flowers. The J. of Horti. Sci. and Biotech., 95(2): 175-182.

Nejatzadeh-Barandozi F, Darvishzadeh F, Aminkhani A. 2014. Effect of nano silver and silver nitrate on seed yield of (Ocimum basilicum L.). Org. Med. Chem. Lett. 4(1): 11.

Pallavi MC, Srivastava R, Arora S, Sharma AK. 2016. Impact assessment of silver nanoparticles on plant growth and soil bacterial diversity, 3 Biotech, 6(2): 254.

Rabiza-Świder J, Skutnik E, Jędrzejuk A, RochalaWojciechowska J. 2020. Nanosilver and sucrose delay the senescence of cut snapdragon flowers. Postharvest Biology and Technology, 165: 111165 .

Royal Flora Holland 2019. Annual report. Available from: https://jaarverslag2019.royalfloraholland.com/?\&_ga=2.134 $527601.1472844088 .1597918551-$ 326602065.1597918551\#/feiten-encijfers/snijbloemen?_k=t2fr8r [Accessed 20 August 2020].

Salachna P, Byczyńska A, Zawadzińska A, Piechocki R, Mizielińska M. 2019. Stimulatory effect of silver nanoparticles on the growth and flowering of potted oriental lilies. Agronomy, 9(10): 610.

Shams G, Ranjbar M, Amiri A. 2013. Effect of silver nanoparticles on concentration of silver heavy element and growth indexes in cucumber (Cucumis sativus L. negeen). J. Nanopart. Res, 15(5): 1630.

Syu YY, Hung JH, Chen JC, Chuang HW. 2014. Impacts of size and shape of silver nanoparticles on Arabidopsis plant growth and gene expression. Plant Physiol Biochem., 83: 57-64.

Tung HT, Nam NB, Huy NP, Luan VQ, Hien VT, Phuong TTB, Le DT, Loc NH, Nhut DT. 2018. A system for large scale production of chrysanthemum using microponics with the supplement of silver nanoparticles under light-emitting diodes. Sci. Hortic, 232: 153-161.

Zari H, Babak P, Asad R. 2015. The effect of priming with nanosliver on agronomic traits of safflower cultivars. J. of Essential Oil-Bearing Plants, 18(5): 1148-1156. 